\title{
Meningkatkan Hasil Belajar Fisika Melalui Penerapan Model Pembelajaran Kooperatif Tipe Student Facilitator and Explaining (SFAE) Pada Siswa Kelas VIIID SMP Negeri 5 Palu
}

\author{
Nirsam, Muhammad Ali* dan Kamaluddin \\ *email: muhammadalihatibe@yahoo.com \\ Prodi Pendidikan Fisika FKIP Universitas Tadulako \\ Jl. Soekarno Hatta KM. 9
}

\begin{abstract}
Abstrak - Penelitian tindakan kelas ini bertujuan untuk meningkatkan hasil belajar fisika siswa kelas VIIID SMP Negeri 5 Palu. Masalah yang diteliti adalah rendahnya hasil belajar siswa pada mata pelajaran IPA Fisika. Alternatif pemecahan masalah adalah menerapkan model pembelajaran kooperatif tipe student facilitator and explaining. Subyek penelitian adalah siswa kelas VIIID SMP Negeri 5 Palu, dengan jumlah siswa 30 orang. Penelitian ini dilaksanakan dalam dua siklus dengan materi pokok cahaya, masing-masing siklus meliputi 4 tahap: (i) perencanaan (ii) pelaksanaan tindakan (iii) observasi (iv) refleksi. Penerapan model pembelajaran kooperatif tipe student facilitator and explaining dapat meningkatkan hasil belajar fisika siswa kelas VIIID. Hal ini dapat dilihat pada peningkatan hasil belajar siswa dari siklus I ke siklus II. Untuk hasil belajar siklus I diperoleh nilai ketuntasan belajar klasikal sebesar 73,33\% dan daya serap klasikal 71,78\%. Sedangkan pada siklus II diperoleh nilai ketuntasan belajar klasikal sebesar $86,67 \%$ dan daya serap klasikal $84,00 \%$ yang artinya sudah melebihi standar ketuntasan belajar siswa, peningkatan daya serap klasikal dari siklus I ke siklus II sebesar 12,22\% dan ketuntasan belajar klasikal dari siklus I ke siklus II sebesar 13,34\%. Untuk hasil observasi aktivitas siswa dan guru pada siklus I yaitu kurang dan cukup, sedangkan pada siklus II berada pada kategori baik dan sangat baik.
\end{abstract}

Kata Kunci: Model Pembelajaran Kooperatif, Kooperatif Tipe Student Facilitator and Explaining, Hasil Belajar Fisika.

\section{PENDAHULUAN}

Proses belajar mengajar dikatakan berhasil apabila hasilnya membawa perubahan yang artinya dalam proses belajar mengajar, guru dan siswa dituntut untuk menghasilkan perubahan dalam pengetahuan, kemampuan, nilai, sikap dan sifat-sifat pribadi, agar proses itu berlangsung dengan efektif dan efisien. Dalam proses pembelajaran masih sering ditemui adanya kecenderungan meminimalkan keterlibatan siswa. Dominasi guru dalam proses pembelajaran menyebabkan kecenderungan siswa lebih bersifat pasif sehingga mereka lebih banyak menunggu sajian guru daripada mencari dan menemukan sendiri pengetahuan, keterampilan atau sikap yang mereka butuhkan.

Berdasarkan hasil observasi awal yang dilakukan di SMP Negeri 5 Palu diperoleh informasi bahwa untuk meningkatkan hasil belajar fisika siswa guru sudah melakukan beberapa metode pembelajaran diantaranya adalah metode penugasan baik di dalam kelas maupun di rumah, ceramah serta remedial bagi siswa yang belum tuntas. Tetapi metode ini belum efektif, dikarenakan selama proses pembelajaran berlangsung, siswa cenderung pasif dan sulit memahami materi yang diberikan oleh guru. Sehingga mengakibatkan minimnya kemampuan siswa untuk mengeluarkan pendapat dan minimnya pemahaman siswa terhadap materi fisika yang diberikan. Hal ini, berdampak pada hasil belajar siswa yang cukup rendah.

Berdasarkan data dan informasi yang diperoleh dari guru mata pelajaran fisika kelas VIIID, bahwa kelas yang memperoleh nilai ratarata hasil belajar fisika pada tengah semester genap tahun 2011/2012 yang masih di bawah standar ketuntasan minimum salah satunya adalah kelas VIIID dengan jumlah siswa yang memiliki nilai di bawah standar rata-rata $(65,0)$ berjumlah 20 orang dari 30 siswa atau sekitar $66,67 \%$. Sedangkan jumlah siswa yang nilainya sudah berada di atas standar rata-rata berjumlah 10 orang atau sekitar 33,33\%. Jika dilihat perbandingan persentase ketuntasan siswa di kelas tersebut masih tergolong rendah. Untuk mengatasi kesulitan belajar siswa seorang guru dituntut untuk memiliki kemampuan mengembangkan model pembelajaran yang efektif terutama pada mata pelajaran fisika. 
Terkait dengan permasalahan di atas, peneliti mencoba menerapkan suatu model pembelajaran yaitu Model pembelajaran kooperatif tipe student facilitator and explaining. Model pembelajaran ini membiasakan siswa untuk bisa bekerja sama dan menggali kreatifitas mereka serta menumbuhkan rasa saling menghargai.

Berdasarkan penelitian sebelumnya, model pembelajaran ini pernah diterapkan oleh Supardin dan diperoleh kesimpulan bahwa terdapat perbedaan kemampuan berpikir kritis antara siswa yang mengikuti model pembelajaran kooperatif tipe student fasilitator and explaining dengan pembelajaran konvensional pada siswa kelas X SMA Negeri 1 Balaesang, yang mana kemampuan berpikir kritis siswa yang mengikuti pembelajaran kooperatif tipe student fasilitator and explaining lebih meningkat dibandingkan siswa yang mengikuti pembelajaran konvensional. Ref.[1]

\section{METODOLOGI PENELITIAN}

Penelitian ini merupakan penelitian tindakan kelas (PTK) yang dilakukan dalam dua siklus. Masing-masing siklus melalui tahap perencanaan, tindakan, observasi, dan refleksi. Tahapan penelitian ini diadopsi dari alur PTK model Kurt Lewin yang dikembangkan oleh Kemmis dan Mc.Taggart. Ref. [2].

Subyek penelitian ini adalah seluruh siswa kelas VIIID SMP Negeri 5 Palu yang terdaftar pada semester genap tahun ajaran 2011/2012 yang berjumlah 30 orang siswa yang terdiri dari 16 orang siswa laki-laki dan 14 orang siswa perempuan, metode pengumpulan data pada penelitian ini, meliputi beberapa cara yaitu, observasi menggunakan lembar observasi dan tes hasil belajar. Faktor-faktor yang diteliti dalam penelitian ini adalah aktivitas guru, aktivitas siswa, efektifitas individu dan kinerja kelompok, serta hasil belajar siswa. Analisa data terbagi menjadi dua kelompok yaitu analisa data kuantitatif dan data kualitatif. Ref. [3]

Hipotesis tindakan pada penelitian ini adalah melalui penerapan model pembelajaran kooperatif tipe student facilitator and explaining dapat meningkatkan hasil belajar fisika pada siswa kelas VIIID SMP Negeri 5 Palu.

\section{HASIL DAN PEMBAHASAN}

Pelaksanaan pembelajarn fisika dengan penerapan model pembelajaran kooperatif tipe student fasilitator and explaining pada penelitian ini dijelaskan sebagai berikut.

Pelaksanaan pembelajaran pada siklus I dilakukan dengan menggunakan metode diskusi kelompok, presentasi, dan tanya jawab. Pelaksanaan pemeblajaran ini ditunjang dengan Skenario Pembelajaran, RPP, Lembar Observasi Aktivitas Guru, Lembar Observasi Siswa, Lembar Observasi Efektifitas Siswa, lembar observasi kinerja kelompok, Lembar Evaluasi Siswa, dan Peta Konsep yang telah disesuaikan. Siswa melakukan kegiatan diskusi kelompok, membuat peta konsep, mempresentasikan hasil diskusi kelompoknya di depan kelas dan menjawab pertanyaan-pertanyaan pada Lembar Evaluasi Siswa yang telah disediakan. Setalah dua kali pertemuan, selanjutnya dilakukan evaluasi terhadap hasil belajar siswa.

Kekurangan dari pembelajaran pada siklus I adalah guru kurang maksimal dalam menerangan kembali semua materi yang disajikan pada saat itu, siswa kurang memperhatikan dan menanggapi motivasi serta menyimak tujuan pembelajaran yang disampaikan oleh guru, siswa kurang menyimak materi yang disampaikan oleh guru, kurang maksimal mempresentasikan hasil diskusi kelompoknya kepada kelompok lain, siswa kurang menyimak kesimpulan yang dikemukakan oleh guru, siswa kurang mampu menyimpulkan materi yang telah dipelajari, hasil belajar siswa sudah cukup baik akan tetapi masih berada di bawah standar ketuntasan belajar klasikal dan sebagian besar siswa tidak mampu menyelesaikan soal-soal perhitungan dengan baik.

Pembelajaran pada siklus II dilaksanakan untuk memperbaiki pembelajaran pada siklus I. Pelaksanaan pembelajaran pada siklus II berjalan lancar sesuai dengan rencana. Siswa terlihat aktif melakukan kegiatan pembelajaran.

Hasil belajar siswa secara lengkap ditunjukkan oleh Tabel 1.

Tabel 1. HASIL BELAJAR SISWA SIKLUS I DAN SIKLUS II

\begin{tabular}{|c|l|c|c|}
\hline \multirow{2}{*}{ No. } & \multicolumn{1}{|c|}{ Aspek Perolehan } & \multicolumn{2}{c|}{ Hasil } \\
\cline { 3 - 4 } & & Suklus I & Siklus II \\
\hline 1. & Skor maksimal & 15 & 15 \\
\hline 2. & Skor tertinggi & 14 & 15 \\
\hline 3. & $\begin{array}{l}\text { Banyak siswa yang } \\
\text { memperoleh skor tertinggi }\end{array}$ & 1 orang & 2 orang \\
\hline 4. & Skor terendah & 7 & 9 \\
\hline 5. & $\begin{array}{l}\text { Banyak siswa yang } \\
\text { memperoleh skor terendah }\end{array}$ & 1 orang & 4 orang \\
\hline 6. & Skor Rata-rata siswa & 10,77 & 12,6 \\
\hline 7. & $\begin{array}{l}\text { Banyaknya siswa yang } \\
\text { tuntas }\end{array}$ & $\begin{array}{c}22 \\
\text { orang }\end{array}$ & orang \\
\hline 8. & $\begin{array}{l}\text { Banyaknya siswa yang tidak } \\
\text { tuntas }\end{array}$ & 8 orang & 4 orang \\
\hline 9. & Persentase daya serap & 71,78 & 84,00 \\
\hline
\end{tabular}




\begin{tabular}{|c|l|c|c|}
\hline & klasikal & $\%$ & $\%$ \\
\hline \multirow{2}{*}{10.} & $\begin{array}{l}\text { Persentase ketuntasan } \\
\text { belajar klasikal }\end{array}$ & $\begin{array}{c}73,33 \\
\%\end{array}$ & $\begin{array}{c}86,67 \\
\%\end{array}$ \\
\hline
\end{tabular}

Berdasarkan analisa tes hasil yang dilakukan pada siklus I, diketahui bahwa hasil belajar fisika siswa kelas VIIID SMP Negeri 5 Palu sudah cukup baik, hanya ada 8 siswa dari 30 siswa yang tidak memenuhi standar ketuntasan individu (65\%) sedangkan ketuntasan belajar klasikal (KBK) siswa mencapai 73,33\% dan daya serap klasikal (DSK) siswa mencapai $71,78 \%$, akan tetapi hasil ini belum memenuhi standar ketuntasan belajar klasikal dan daya serap klasikal yang harus mencapai $80 \%$.

Dilihat dari hasil observasi aktivitas guru dan siswa diketahui bahwa tidak tuntasnya hasil belajar siswa ini disebabkan oleh beberapa faktor yaitu: guru kurang maksimal dalam menerangkan kembali semua materi yang disajikankan saat itu, dalam hal ini guru kurang maksimal meminta siswa untuk mencatat halhal penting yang dijelaskan dan kurang memberikan kesempatan kepada siswa untuk bertanya sehingga siswa kurang mencatat materi-materi penting yang disampaikan oleh guru dan kurang menanyakan hal-hal yang belum dimengerti. Guru kurang maksimal dalam memberikan motivasi dan menyampaikan tujuan pembelajaran, dalam hal ini kurang memancing siswa untuk aktif dalam kegiatan pembelajaran sehingga siswa kurang menyimak dan memberikan tanggapan atas motivasi dan tujuan pembelajaran yang disampaikan guru. Guru kurang memberikan kesempatan kepada kelompok lain untuk menanggapi hasil presentasi kelompok yang tampil sehingga siswa kurang maksimal dalam menjawab pertanyaan dari kelompok yang lain dan kurang memberikan kesempatan kepada kelompok lain untuk bertanya. Guru kurang maksimal menyimpulkan ide atau pendapat yang berkembang dari siswa, dalam hal ini kurang meminta siswa untuk memperhatikan simpulan yang diambil oleh guru sehingga siswa kurang mencatat hal yang penting dan mengoreksi pendapat mereka yang keliru serta memperbaikinya. Guru kurang maksimal membimbing siswa membuat kesimpulan dari materi yang telah dipelajari, dalam hal ini kurang mengarahkan siswa untuk membuat kesimpulan hasil diskusi sehingga siswa kurang mampu menyampaikan kesimpulan sesuai tujuan pembelajaran dan kurang menyimak kesimpulan akhir dari guru. Guru kurang maksimal mengkoordinir siswa untuk bergabung dalam kelompok belajar, dalam hal ini kurang meminta siswa untuk bekerjasama dengan teman kelompoknya sehingga siswa kurang bekerjasama dengan anggota kelompoknya. Guru kurang memberikan kesempatan kepada masing-masing kelompok untuk mendiskusikan materi dan menuangkannya kedalam peta konsep, dalam hal ini meminta siswa untuk mendiskusikan kembali bersama teman kelompoknya hasil dari pekerjaan mereka sehingga siswa kurang menanyakan hal-hal yang belum dimengerti. Sebagaimana dapat dilihat dari hasil analisis aktivitas guru masih berada pada kategori cukup dan baik dan aktivitas siswa masih berada pada kategori kurang dan cukup. Hasil ini dapat di gambarkan seperti Gambar 1.

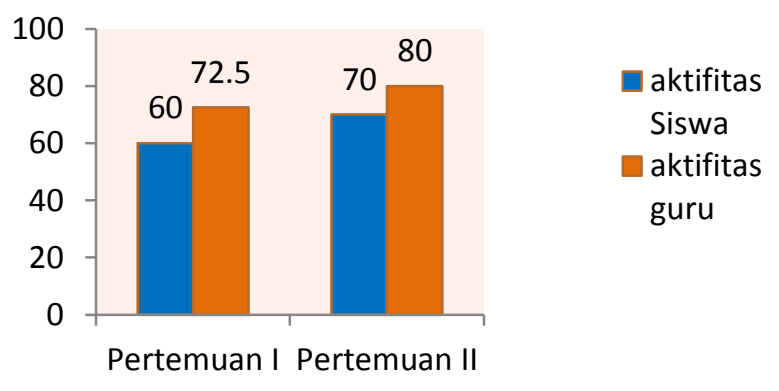

Gambar 1. Grafik Aktivitas Siswa dan Aktivitas Guru

Dari hasil penilaian afektivitas siswa dan kinerja kelompok juga diketahaui bahwa masih ada beberapa siswa yang sering terlambat dalam mengikuti pelajaran, siswa kurang memberikan pertanyaan, siswa kurang berkonsentrasi saat mengikuti pelajaran, siswa belum maksimal dalam mencari materi yang sesuai dengan tujuan pembelaran untuk dituangkan ke dalam peta konsep, sebagian besar kelompok kurang bertukar pendapat dalam menyelesaikan peta konsep, sebagian besar kelompok kurang bersungguh-sungguh dalam melakukan presentasi dan menjawab pertanyaan seadanya, sebagian kelompok masih belum mampu menjawab pertanyaan dengan tepat, sebagian besar anggota kelompok kurang membantu temannya ketika ada pertanyaan yang sulit. Dari hasil analisis afektivitas siswa dan kinerja kelompok diketahui bahwa aspek-aspek yang diamati masih berada pada kategori cukup dan baik.

Dari hasil wawancara juga diketahui bahwa siswa masih sulit mengerjakan soal-soal terutama soal perhitungan hal ini desebabkan karena saat melakukan evaluasi guru kurang membimbing siswa dalam mengerjakan soalsoal perhitungan, guru terlalu cepat dalam menyampaikan materi sehingga siswa kurang menyimak materi yang disampaikan oleh guru, 
kurangnya perhatian siswa saat proses pembelajaran berlangsung dan terkesan bermain-main sehingga siswa tidak mampu menjawab evaluasi yang diberikan oleh guru, akan tetapi siswa juga merasa senang dengan model pembelajaran yang guru terapkan walaupun pada awal pertemuan ada beberapa siswa yang masih malu-malu saat melakukan presentasi di depan temannya dan masih bingung karena belum terbiasa dengan model pembelajaran yang diterapkan. Dari beberapa penyebab yang dikemukakan di atas, peneliti harus lebih berusaha untuk memperbaiki kemampuan dalam mengelolah kelas dengan baik agar kemampuan siswa bisa lebih meningkat.

Pada siklus II, peneliti berusaha meminimalisir beberapa penyebab yang mengakibatkan hasil belajar siswa pada siklus I belum memenuhi indikator keberhasilan kuantitatif dan kualitatif, agar bisa meningkat dan bisa memenuhi standar tersebut. Beberapa usaha yang dilakukan peneliti yaitu: peneliti lebih tenang dalam menyampaikan materi, serta menggunakan bahasa yang lebih mudah dipahami oleh siswa, peneliti menciptakan suasana keakraban terhadap siswa, selalu memotivasi dan menubuhkan rasa percaya diri siswa serta memberikan kesempatan bertanya lebih banyak dari pertemuan sebelumnya, peneliti berusaha mengkoordinir setiap siswa sehingga bisa mengerjakan atau menjawab soal-soal terutama soal perhitungan, peneliti menyediakan karton yang bertuliskan tujuan pembelajaran.

Berdasarkan analisis tes hasil belajar siklus II, diketahui bahwa hasil belajar siswa sudah memenuhi indikator keberhasilan kuantitatif dengan ketuntasan belajar klasikal (KBK) siswa mencapai $86,67 \%$ dan daya serap klasikal (DSK) siswa mencapai $84,00 \%$ serta hanya ada 4 siswa yang belum memenuhi standar ketuntasan individu. Dari hasil analisis kualitatif, diketahui bahwa peran siswa yang sesuai dengan skenario pembelajaran dalam kegiatan belaja-mengajar telah terarah dengan baik. Hal ini dapat dilihat dari hasil analisis lembar observasi aktivitas guru dan siswa yang meningkat yaitu pada kategori baik dan sangat baik, selain itu penilaian afektivitas individu dan kinerja kelompok yang juga mengalami peningkatan yaitu berada pada kategori baik dan sangat baik, serta proses pembelajaran yang tidak didominasi oleh siswa yang pintar saja. Dari hasil wawancara juga dapat diketahui bahwa siswa sudah mampu menyelesaikan soal-soal perhitungan dan siswa senang dengan model pembelajaran yang diterapkan oleh guru (peneliti).

Hasil yang diperoleh pada siklus II dapat meningkat dan lebih baik dari siklus I karena faktor-faktor penyebab kegagalan pada siklus I dapat diminimalisir. Peningkatan hasil belajar siswa dari siklus I ke siklus II dapat dilihat pada Gambar 2.

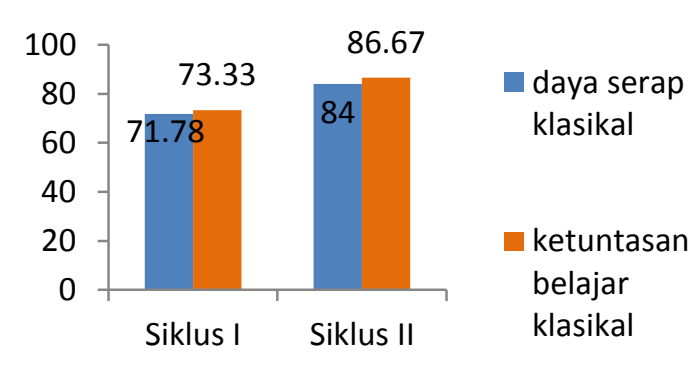

Gambar 2. Grafik Hasil Belajar Siswa Siklus I dan II

Berdasarkan Gambar 2 diketahui bahwa peningkatan Daya Serap Klasikal dan Ketuntasan Belajar Klasikal dari siklus I ke siklus II sebesar $12,22 \%$ dan $13,34 \%$. Berdasarkan uraian di atas, dapat dikatakan bahwa model pembelajaran kooperatif tipe student facilitator and explaining dapat meningkatkan hasil belajar fisika siswa kelas VIIID SMP Negeri 5 Palu

\section{KESIMPULAN}

Berdasarkan hasil analisa data dan pembahasan pada penelitian ini, maka dapat disimpulkan bahwa penerapan model pembelajaran kooperatif tipe student facilitator and explaining dapat meningkatkan hasil belajar fisika pada siswa kelas VIIID SMP Negeri 5 Palu. Hal ini dapat dilihat pada peningkatan hasil belajar siswa dari siklus I ke siklus II. Untuk hasil belajar siklus I diperoleh nilai ketuntasan belajar klasikal sebesar $73,33 \%$ dan daya serap klasikal $71,78 \%$. Sedangkan pada siklus II diperoleh nilai ketuntasan belajar klasikal sebesar $86,67 \%$ dan daya serap klasikal $84,00 \%$ yang artinya sudah melewati standar ketuntasan klasikal siswa, peningkatan DSK dan KBK dari siklus I ke siklus II sebesar $12,22 \%$ dan $13,34 \%$. Untuk hasil observasi aktivitas siswa dan guru pada siklus I berada pada kategori kurang dan cukup, sedangkan pada siklus II berada pada kategori baik dan sangat baik dan hasil wawancara menunjukkan bahwa siswa senang dengan model pembelajaran yang diterapkan. 


\section{DAFTAR PUSTAKA}

[1] Depdiknas. 2004. Penelitian Tindakan Kelas. Jakarata: Direktorat Pendidikan Nasional

[2] Supardin. 2012. Pengaruh Model Pembelajaran Student Fasilitator and Explaining Terhadap Kemampuan Berpikir Kritis Pada Siswa Kelas X Sma Negeri 1 Balaesang. Skripsi tidak dipublikasikan. Palu: FKIP UNTAD

[3] Tim Penyusun. 2005. Pedoman Penyusunan dan Penilaian Karya Ilmiah. Palu: FKIP UNTAD. 